\title{
Antibacterial potential of extracts of various parts of Catunaregam tomentosa (Blume ex DC) Tirveng and their effects on bacterial granularity and membrane integrity
}

\author{
Karnsiree Thimabut ${ }^{1}$, Amornrat Keawkumpai ${ }^{1}$, Patima Permpoonpattana ${ }^{1}$, \\ Saranyoo Klaiklay ${ }^{2}$, Parinuch Chumkaew ${ }^{2}$, Darika Kongrit ${ }^{1}$, Jaraslak \\ Pechwang $^{1}$, Theera Srisawat ${ }^{1 *}$ \\ ${ }^{1}$ Department of Agricultural Science and Technology, ${ }^{2}$ Department of Applied Chemistry, Faculty of Science and Industrial \\ Technology, Prince of Songkla University, Suratthani Campus, 31 Moo 6 Thumbol Makhamtia, Muang, Suratthani 84000, \\ Thailand
}

*For correspondence: Email: theera.s@psu.ac.th; Tel: +66-077355453

Sent for review: 12 May 2017

Revised accepted: 18 April 2018

\begin{abstract}
Purpose: To investigate the antibacterial activity of extracts from Catunaregam tomentosa on Bacillus subtilis and Staphylococcus aureus, and the bacterial responses to the extracts.

Methods: The antibacterial activity of fruit, leaf and stem bark extracts were evaluated against $B$. subtilis (ATCC6633) and $S$. aureus (ATCC25923). Using a disc diffusion method, extracts at concentrations ranging from $50-1,000 \mu \mathrm{g} /$ disc were tested. The minimum inhibitory (MIC) and minimum bactericidal concentrations $(M B C)$ of the extracts against the test bacteria were determined. Fluorescent activated cell sorting (FACS) was used to assess the responses of both types of bacteria to the extracts.

Results: The fruit and leaf extracts at 1,000 $\mu \mathrm{g} /$ disc showed optimum efficacy against $B$. subtilis and $S$. aureus with MIC of $1,000 \mu \mathrm{g} / \mathrm{mL}$ against both $B$. subtilis and S. aureus, for the fruit and the leaf extracts. With increasing doses of fruit and leaf extracts at $6 \mathrm{~h}$ of incubation, FACS profiles revealed that cell death for $B$. subtilis increased. The fruit and leaf extracts of $C$. tomentosa also exhibited antibacterial activity against $S$. aureus in a dose- and time-dependent manner. The bacteria initially lost their granularity, then lost membrane integrity, and consequently died.

Conclusion: The fruit and leaf extracts of $C$. tomentosa exhibit significant antibacterial potential against Gram-positive bacteria by damaging bacterial granularity and membrane integrity.
\end{abstract}

Keywords: Catunaregam tomentosa, Flow cytometry, Programmed cell death, Response pattern, Bacterial granularity, Membrane integrity

This is an Open Access article that uses a funding model which does not charge readers or their institutions for access and distributed under the terms of the Creative Commons Attribution License (http://creativecommons.org/licenses/by/4.0) and the Budapest Open Access Initiative (http://www.budapestopenaccessinitiative.org/read), which permit unrestricted use, distribution, and reproduction in any medium, provided the original work is properly credited.

Tropical Journal of Pharmaceutical Research is indexed by Science Citation Index (SciSearch), Scopus, International Pharmaceutical Abstract, Chemical Abstracts, Embase, Index Copernicus, EBSCO, African Index Medicus, JournalSeek, Journal Citation Reports/Science Edition, Directory of Open Access Journals (DOAJ), African Journal Online, Bioline International, Open-J-Gate and Pharmacy Abstracts

\section{INTRODUCTION}

In recent years multidrug-resistant (MDR) pathogenic bacteria have been increasingly reported, largely due to a history of indiscriminate use of various antibiotics. This process selects for the resistant strains, killing off the competing non-resistant bacterial population. MDR strains 
are therefore common in connection with infections, such as gastritis, urinary tract infections, encephalitis, and food poisoning [1,2]. In addition, in 2014, the World Health Organization reported that MDR strains are now a major threat to public health, as no antibiotic has efficacy against them.

Thus, it is necessary to search for novel alternatives, using plant and animal natural products as potential sources of antibacterial drugs. Traditional medicine tends to rely on medicinal herbal plants, and such medicinal plants may provide novel phytochemicals to use as bactericides [3]. The use of medicinal herbal plants has been promoted as effective against infectious diseases, but with fewer side effects than synthetic drugs.

Many plant families are of current interest in medicinal research. Interestingly, various parts of the plants in the genus Rubiaceae have been reported to have significant antibacterial efficacies [4,5]. For instance, the roots of Catunaregam tomentosa reportedly have antibacterial properties against some Gram positive bacteria [6]. In traditional medicine, the roots of $C$. tomentosa have been used by healers for stomatitis and ulcer therapies. However, in Thai traditional medicine, while the roots of this plant are designated for treating infectious symptoms and in vivo for antibacterial effects, the aerial parts of the plant, such as fruit, leaf, and stem bark, have not been measured for their potential bioactive activity.

In the present study, we tested the activities of $C$. tomentosa fruit, leaf, and stem bark extracts against Bacillus subtilis and Staphylococcus aureus, and assessed the bacterial population responses to these extracts.

\section{EXPERIMENTAL}

\section{Plant materials and extract preparation}

Fresh plant tissue samples (fruit, leaf, and stem bark) were collected from 10-year old $C$. tomentosa from the Chaiya District, Suratthani Province, Thailand. The samples were washed separately under running tap water and dried. Each dried sample (125 g) was soaked in $99 \%$ methanol for 5 days, and the suspension was filtered with two cotton layers. The methanolic filtrate was concentrated in a rotary evaporator at $45^{\circ} \mathrm{C}$ until a sticky mass was obtained. The sticky mass was weighed and then stored at $4{ }^{\circ} \mathrm{C}$ until further use. These constituted the three concentrated extracts, representing fruit, leaf, and stem bark.

\section{Test microorganisms}

The bacterial strains tested for antimicrobial activity by $C$. tomentosa extracts were $B$. subtilis (ATCC6633), and $S$. aureus (ATCC25923). The bacterial strains were obtained by and maintained at the Scientific Laboratory and Equipment Center, Prince of Songkla University, Surat Thani campus, Thailand.

The bacterial strains were cultured on nutrient agar (NA) plates and incubated for 18 to $24 \mathrm{~h}$ at $37^{\circ} \mathrm{C}$. A single colony was then cultured in 50 $\mathrm{mL}$ nutrient broth (NB) for $4 \mathrm{~h}$ at $37^{\circ} \mathrm{C}$. The turbidity of the bacterial culture required for the tests was adapted to $0.5 \mathrm{McF}$ arland standard, $\left(1.0 \times 10^{7}\right.$ colony forming units $\left./ \mathrm{mL}\right)$ and was measured with a spectrophotometer (Thermo Fisher Scientific, Madison, WI, USA).

\section{Disc diffusion assay}

Antibacterial activities of the extracts were estimated by the disc diffusion method on trypticase soy agar. Sterile cotton swabs were dipped into the bacterial strain suspension (at $1 \times$ $10^{7} \mathrm{CFU} / \mathrm{mL}$ ) and used to uniformly inoculate the whole surface of an agar plate. Filter paper discs (6 $\mathrm{mm}$ diameter) were used to absorb $25 \mu \mathrm{L}$ of an extract in aqueous solution, at concentrations that gave $50,100,250,500$, or $1,000 \mu \mathrm{g} /$ disc of the extract. The discs were air dried and placed on the inoculated agar. The agar plates were then incubated for $24 \mathrm{~h}$ at $37^{\circ} \mathrm{C}$. The standard antibiotic disc (positive control) had oxytetracycline (OTC) at $30 \mu \mathrm{g} / \mathrm{disc}$, and the negative control discs contained $10 \%$ dimethyl sulfoxide (DMSO).

Determination of minimum inhibitory (MIC) and minimum bactericidal concentrations (MBC)

MIC was determined for each type of plant extract that gave clearly positive results in the disc diffusion test. The determination used twofold serial dilutions, with extract concentrations of $1,000,500,250,125,62.5,31.25,15.62,7.81$, 3.90 , and $1.95 \mu \mathrm{g} / \mathrm{mL}$. One $\mathrm{mL}$ of extract solution was added to the first tube containing $1 \mathrm{~mL}$ of sterile trypticase soy broth with $1 \times 10^{7} \mathrm{CFU} / \mathrm{mL}$ bacteria, resulting in a final concentration of extract of $1,000 \mu \mathrm{g} / \mathrm{mL}$. Then, $1 \mathrm{~mL}$ of this solution was transferred to the next tube containing $1 \mathrm{~mL}$ of $1 \times 10^{7} \mathrm{CFU} / \mathrm{mL}$ bacteria, for a two-fold dilution.

These steps were repeated nine times to create the dilution series. DMSO served as the negative control, and the positive control was 
oxytetracycline at $30 \mu \mathrm{g} / \mathrm{mL}$. The culture was incubated at $37^{\circ} \mathrm{C}$ for $24 \mathrm{~h}$. The MIC was determined as the final dilution of extract that showed growth inhibition of the microorganisms. The MBC was determined after the MIC determination. The cultures in the tubes that showed no turbidity were each spread on an NA plate. The plates were incubated overnight at 37 ${ }^{\circ} \mathrm{C}$, and the lowest concentration without bacterial growth was recorded as the MBC.

\section{Fluorescent activated cell sorting (FACS) analysis}

Bacterial strains were grown to the midlogarithmic phase $\left(1 \times 10^{7} \mathrm{CFU} / \mathrm{mL}\right)$, and then the cultures were harvested and $1 \mathrm{~mL}$ of each bacterial strain was placed in a microcentrifuge tube. Each sample was centrifuged at 8,000 rpm for $10 \mathrm{~min}$, and then the extracts were added at concentrations of $0.5 \times \mathrm{MIC}, 1 \times \mathrm{MIC}$, and $2 \times$ MIC. While exposed to a range of extract concentrations, the bacteria were incubated at 37 ${ }^{\circ} \mathrm{C}$ for $3 \mathrm{~h}$ and $6 \mathrm{~h}$. After incubation, the samples were centrifuged at $8,000 \mathrm{rpm}$ for $10 \mathrm{~min}$, and then washed twice with $950 \mu \mathrm{L}$ phosphatebuffered saline. Each sample was mixed with propidium iodide (PI; $30 \mu \mathrm{g} / \mathrm{mL}$ ) and incubated for $15 \mathrm{~min}$ at room temperature in darkness, before testing with flow cytometry.

Flow cytometry procedures and interpretations of the FACS profiles followed previously published methods [7]. Briefly, when a density plot of the cell population was made in the $\mathrm{Pl}$ and side scatter (SSC) quadrants, the treated cells were labeled according to their quadrant: lower left represented viable cells (PI-, SSC-), lower right represented membrane-damaged cells $(\mathrm{PI}+$ SSC-), upper left represented injured cells (PI-, SSC+), and upper right represented dead cells
$(\mathrm{PI}+, \mathrm{SSC}+)$. The transition from healthy viable bacteria to those killed by a treatment was assessed from the FACS data. The percentage of dead bacteria were also counted and compared between alternative treatments.

\section{Statistical analysis}

The data are presented as mean \pm SD and were analyzed by analysis of variance (ANOVA). Comparisons of the means between treatments were performed using the Duncan's Multiple Range test. $P<0.05$ was considered statistically significant. The data obtained from antibacterial studies were analyzed using SPSS statistical software, version 11.0 (SPSS Inc., Chicago, IL, USA).

\section{RESULTS}

\section{Antibacterial activity}

The antimicrobial activities of $C$. tomentosa fruit, leaf, and stem bark extracts were studied with two types of Gram positive bacteria. The extract exhibited antibacterial properties as shown in Table 1. The zones of inhibition by the leaf extract against $B$. subtilis and $S$. aureus were from $8.0 \mathrm{~mm}-12.67 \mathrm{~mm}$, and the $1,000 \mu \mathrm{g} / \mathrm{disc}$ dose was the most effective. The maximal inhibition zones were observed with the fruit extract of $C$. tomentosa at $1,000 \mu \mathrm{g} /$ disc, these being $12.23 \mathrm{~mm}$ with $B$. subtilis and $12.17 \mathrm{~mm}$ with $S$. aureus. Thus, both types of bacteria were sensitive to the fruit and the leaf extracts of $C$. tomentosa. However, the stem bark extract did not exhibit antibacterial activity against the tested bacteria. Therefore, only the fruit and leaf extracts were used in subsequent experiments.

Table 1: In vitro antibacterial activity of the plant extract

\begin{tabular}{|c|c|c|c|c|c|c|}
\hline \multirow{3}{*}{$\begin{array}{l}\text { Dose of } \\
\text { extract } \\
\text { ( } \mu \mathrm{g} / \mathrm{disc})\end{array}$} & \multicolumn{6}{|c|}{ Diameter of zone of inhibition (mm) } \\
\hline & \multicolumn{3}{|c|}{ Bacillus subtilis } & \multicolumn{3}{|c|}{ Staphylococcus aureus } \\
\hline & $\begin{array}{c}\text { Fruit } \\
\text { extract }\end{array}$ & $\begin{array}{c}\text { Leaf } \\
\text { extract } \\
\end{array}$ & $\begin{array}{c}\text { Stem bark } \\
\text { extract }\end{array}$ & $\begin{array}{l}\text { Fruit } \\
\text { extract }\end{array}$ & $\begin{array}{c}\text { Leaf } \\
\text { extract }\end{array}$ & $\begin{array}{c}\text { Stem bark } \\
\text { extract }\end{array}$ \\
\hline OTC & & & & & & \\
\hline 30 & $22.67 \pm 0.57^{\mathrm{a}}$ & $23.33 \pm 1.53^{\mathrm{a}}$ & $22.67 \pm 1.53$ & $35.33 \pm 1.04^{a}$ & $35.17 \pm 0.76^{a}$ & $35.33 \pm 0.58$ \\
\hline 50 & - & - & - & - & - & - \\
\hline 100 & - & $8 \pm 1.0^{\mathrm{d}}$ & - & - & - & - \\
\hline 250 & - & $10.33 \pm 0.57^{c}$ & - & - & $9.33 \pm 0.58^{\mathrm{C}}$ & - \\
\hline 500 & $11 \pm 2.65^{\mathrm{b}}$ & $11.67 \pm 0.57^{\mathrm{bc}}$ & - & $11.17 \pm 0.29^{c}$ & $10 \pm 1.0^{\mathrm{b}}$ & - \\
\hline 1,000 & $12.23 \pm 0.57^{\mathrm{D}}$ & $12.67 \pm 0.57^{\mathrm{D}}$ & - & $12.17 \pm 0.29^{b}$ & $12 \pm 0.5^{\mathrm{b}}$ & - \\
\hline 10\% DMSO & - & - & - & - & - & - \\
\hline Susceptibility & Sensitive & Sensitive & Resistant & Sensitive & Sensitive & Resistant \\
\hline
\end{tabular}

The zone of inhibition was converted to susceptibility rating as follows: resistant, $\leq 6 \mathrm{~mm}$; susceptible, sensitive, $\geq 12 \mathrm{~mm}$. Values followed by the same superscript letter in a column did not differ statistically significantly (significance means $p<0.05$ ); TC = oxytetracycline; DMSO = dimethyl sulfoxide 
Table 2: Minimum inhibitory (MIC) and minimum bactericidal concentration (MBC) for Catunaregam tomentosa fruit and leaf extracts that had antibacterial activity

\begin{tabular}{lcccc}
\hline $\begin{array}{l}\text { Source } \\
\text { tissue of } \\
\text { extract }\end{array}$ & \multicolumn{3}{c}{ Staphylococcus aureus } & $\begin{array}{c}\text { Bacillus } \\
\text { subtilis }\end{array}$ \\
\cline { 2 - 5 } & $\begin{array}{c}\mathrm{MIC} \\
(\mu \mathrm{g} / \mathrm{mL})\end{array}$ & $\begin{array}{c}\mathrm{MBC} \\
(\mu \mathrm{g} / \mathrm{mL})\end{array}$ & $\begin{array}{c}\mathrm{MIC} \\
(\mu \mathrm{g} / \mathrm{m} \\
\mathrm{L})\end{array}$ & $\begin{array}{c}\mathrm{MBC} \\
(\mu \mathrm{g} / \mathrm{mL})\end{array}$ \\
\hline Fruit & 1,000 & nd & 1,000 & $\mathrm{nd}$ \\
Leaf & 1,000 & nd & 1,000 & nd \\
\hline
\end{tabular}

$\mathrm{Nd}=$ not detectable

\section{Minimum inhibitory and minimum bactericidal concentrations}

As shown in Table 2, it was found that the two bacterial strains tested (B. subtilis and $S$. aureus) were sensitive to both extracts, and the MIC values of these extracts were $1,000 \mu \mathrm{g} / \mathrm{mL}$. Unfortunately, the extracts did not inhibit the growth of bacteria in testing for MBC, so no MBC values were determined.

\section{Membrane granularity and integrity}

Actions of the $C$. tomentosa extracts on bacterial populations, in terms of indicators of granularity and membrane permeability, were investigated from FACS profiles. Flow cytometric profiles, using PI staining to obtain one coordinate and side scatter as the other coordinate, are shown in Figures 1-4. The $C$. tomentosa extracts were used at various concentrations and various exposure times. The results showed that both bacterial strains responded to treatment by the C. tomentosa extracts (Table 3 and Table 4). At $3 \mathrm{~h}$ of incubation with extract from the leaves of C. tomentosa, as the extract concentration increased $(0.5 \times \mathrm{MIC}$ to $1 \times \mathrm{MIC}$ to $2 \times \mathrm{MIC})$, the bacterial population continuously showed changes. First, granularity was lost, followed by loss of membrane permeability, resulting in 3.9 to 16.4 to $25.7 \%$ death rates of $B$. subtilis, and 2.7 to 5.5 to $21.0 \%$ death rates of $S$. aureus at the three MICs, respectively. When the exposure time was $6 \mathrm{~h}$, the $B$. subtilis and $S$. aureus populations again responded continuously (2.1 to 11.5 to $20.5 \%$ death rates, and 8.2 to 11.7 to $34.1 \%$ death rates, respectively, for the MICs). $S$. aureus responded to the leaf extract in a manner dependent on the dose and exposure times, whereas $B$. subtilis responded in a dosedependent manner with little effect from various exposure times. On treatment with the fruit extract of $C$. tomentosa, increasing the doses from $0.5 \times$ MIC to $1 \times$ MIC to $2 \times$ MIC induced $B$. subtilis death both at $3 \mathrm{~h}$ and $6 \mathrm{~h}$ of incubation (1.2 to 4.8 to $21.5 \%$, and 1.6 to 3.2 to $20.1 \%$, respectively), whereas continuous responses involving the mortality of $S$. aureus were observed at $6 \mathrm{~h}$ of incubation (23.7 to 25.2 to $45.7 \%$, for the three MICs, respectively). Both bacterial strains responded to fruit extracts in a dose-dependent manner. The patterns of bacterial response were identified as follows: Injured cells (lost granularity) and dead cells (cells that initially lost granularity followed by lost membrane permeability) could be seen in the upper left quadrant (PI-negative, SSC-positive) and in the upper right quadrant (PI-positive, SSC-positive), respectively, whereas cells that lost membrane permeability were positioned in the lower right quadrant.
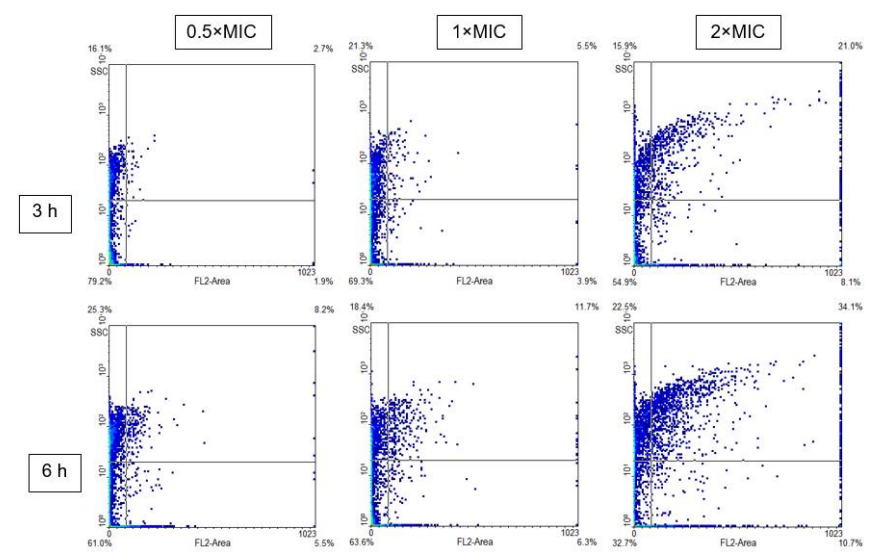

Figure 1: Propidium iodide (PI) staining density plot for the Staphylococcus aureus population treated with a leaf extract of Catunaregam tomentosa for $3 \mathrm{~h}$ and 6 h. MIC, minimum inhibitory concentration. Double negative cells indicate live cell population, PI (or FL2A) positive cells indicate the membrane-damaged population, Side scatter (SSC) positive cells indicate the lost-granularity population and double positive cells indicate death population

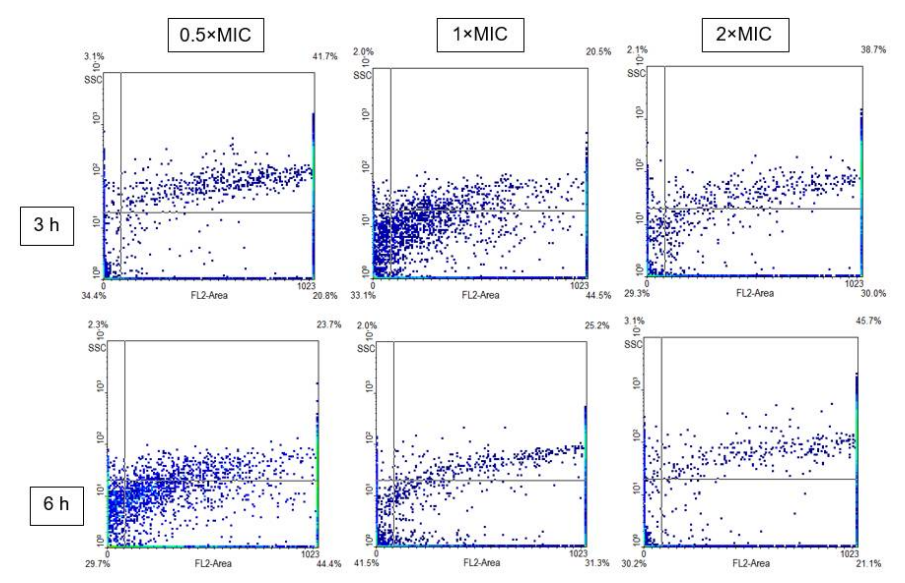

Figure 2: PI staining density plot for the $S$. aureus population treated with a fruit extract of $C$. tomentosa for $3 \mathrm{~h}$ and $6 \mathrm{~h}$. Abbreviations and description of all panels are given in Figure 1 legend 
Table 3: Fractions of Staphylococcus aureus population (in percent) after exposure to extracts of. Catunaregam tomentosa at $3 \mathrm{~h}$ and $6 \mathrm{~h}$ of incubation

\begin{tabular}{|c|c|c|c|c|c|c|c|c|}
\hline \multirow{2}{*}{$\begin{array}{l}\text { Subpopulation } \\
\text { of cells }\end{array}$} & \multicolumn{2}{|c|}{$\mathbf{O h}$} & \multicolumn{3}{|c|}{$3 \mathbf{h}$} & \multicolumn{3}{|c|}{$6 \mathrm{~h}$} \\
\hline & Control & OTC & $0.5 M I C$ & MIC & $2 M I C$ & $0.5 \mathrm{MIC}$ & MIC & $2 M I C$ \\
\hline \multicolumn{9}{|l|}{ Leaf extracts } \\
\hline Non-responder (viable) & 99.9 & 94.1 & 79.2 & 69.3 & 54.9 & 61 & 63.6 & 32.7 \\
\hline Membrane-damaged & - & 0.9 & 1.9 & 3.9 & 8.1 & 5.5 & 6.3 & 1.7 \\
\hline Injured (lost granularity) & - & 4.6 & 16.1 & 21.3 & 15.9 & 25.3 & 18.4 & 22.5 \\
\hline Dead & 0.1 & 0.3 & 2.7 & 5.5 & 21 & 8.2 & 11.7 & 34.1 \\
\hline Total responders & 0.1 & 5.8 & 20.7 & 30.7 & 45 & 39 & 36.4 & 58.3 \\
\hline \multicolumn{9}{|l|}{ Fruit extracts } \\
\hline Non-responder (viable) & 97.5 & 96.9 & 34.4 & 33.1 & 29.3 & 29.7 & 41.7 & 30.2 \\
\hline Membrane-damaged & 1.7 & 0.6 & 20.6 & 44.5 & 30 & 44.4 & 31.3 & 21.1 \\
\hline Injured (lost granularity) & 0.3 & 0.2 & 3.1 & 2 & 2.1 & 2.3 & 2 & 3.1 \\
\hline Dead & 2.5 & 3.1 & 41.7 & 20.5 & 38.7 & 23.7 & 25.2 & 45.7 \\
\hline Total responders & 0.1 & 5.8 & 65.4 & 67 & 70.8 & 70.4 & 58.5 & 69.9 \\
\hline
\end{tabular}

$\mathrm{MIC}=$ minimum inhibitory concentration; OTC = oxytetracycline

Table 4: Fractions of Bacillus subtilis population (in percent) after exposure to extracts of Catunaregam tomentosa at $3 \mathrm{~h}$ and $6 \mathrm{~h}$ of incubation

\begin{tabular}{|c|c|c|c|c|c|c|c|c|}
\hline $\begin{array}{l}\text { Subpopulation } \\
\text { of cells }\end{array}$ & Control & OTC & $0.5 \mathrm{MIC}$ & $\begin{array}{l}3 \mathrm{~h} \\
M I C\end{array}$ & $2 M I C$ & $0.5 \mathrm{MIC}$ & $\begin{array}{l}6 \mathrm{~h} \\
M I C\end{array}$ & $2 M I C$ \\
\hline \multicolumn{9}{|l|}{ Leaf extracts } \\
\hline Non-responder (viable) & 80.3 & 95.5 & 73.6 & 45.3 & 37 & 75.9 & 60.3 & 46.1 \\
\hline Membrane-damaged & 18 & 3.8 & 20.3 & 32.1 & 9.7 & 20.8 & 18.8 & 8.8 \\
\hline Injured (lost granularity) & 0.4 & 0.3 & 2.1 & 6.2 & 27.7 & 1.2 & 9.4 & 24.6 \\
\hline Dead & 1.3 & 0.3 & 3.9 & 16.4 & 25.7 & 2.1 & 11.5 & 20.5 \\
\hline Total responders & 19.7 & 4.4 & 26.3 & 54.7 & 63.1 & 24.1 & 39.7 & 53.9 \\
\hline \multicolumn{9}{|l|}{ Fruit extracts } \\
\hline Non-responder (viable) & 62.9 .3 & 58.2 & 78.7 & 59.6 & 39.8 & 65.5 & 67.2 & 45.5 \\
\hline Membrane-damaged & 18 & 20.9 & 19.7 & 34.8 & 34.8 & 32.4 & 29.1 & 31.1 \\
\hline Injured (Iost granularity) & 9.8 & 10.6 & 0.4 & 0.8 & 4 & 0.5 & 0.5 & 3.3 \\
\hline Dead & 8.7 & 10.3 & 1.2 & 4.8 & 21.5 & 1.6 & 3.2 & 20.1 \\
\hline Total responders & 19.7 & 4.4 & 21.3 & 40.4 & 60.3 & 34.5 & 32.8 & 54.5 \\
\hline
\end{tabular}

$\mathrm{MIC}=$ minimum inhibitory concentration; OTC = oxytetracycline 


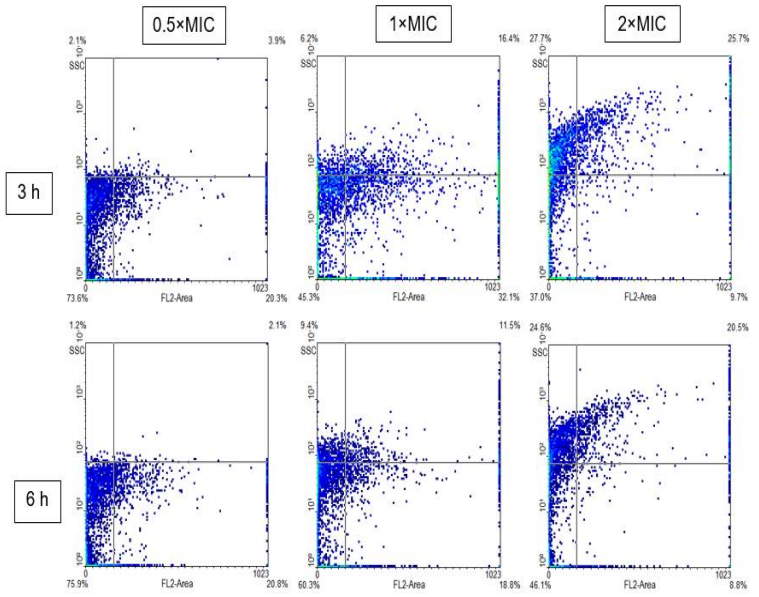

Figure 3: $\mathrm{Pl}$ staining density plot for $B$. subtilis population treated with leaf extracts of $C$. tomentosa for $3 \mathrm{~h}$ and $6 \mathrm{~h}$. Abbreviations and description of all panels are defined in Figure 1 legend

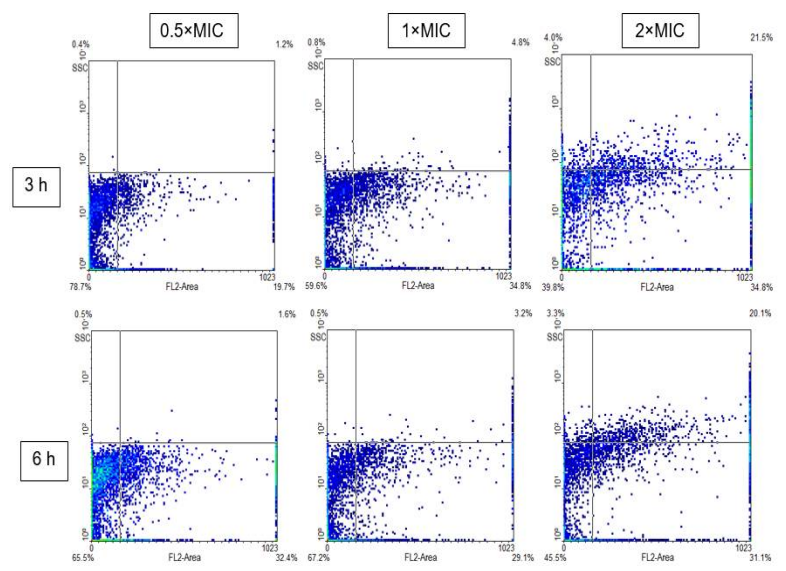

Figure 4: $\mathrm{Pl}$ staining density plot for $B$. subtilis populations treated with a fruit extracts of $C$. tomentosa for $3 \mathrm{~h}$ and $6 \mathrm{~h}$. Abbreviations and description of all panels are defined in Figure 1 legend

\section{DISCUSSION}

In this study, the leaf and fruit extracts of $C$. tomentosa displayed upper-moderate to strong antibacterial activities. The inhibition zones of bacteria exposed to $C$. tomentosa extracts indicated that these extracts inhibited the growth of $B$. subtilis and $S$. aureus. Extract doses of 500 - 1,000 $\mu \mathrm{g} /$ disc gave satisfactory clear zone sizes $(8-12 \mathrm{~mm})$. Although $C$. tomentosa has earlier been reported by Wutithamawech et al [6] as a treatment for bacterial infectious symptoms used as a root extract, the root extract did not inhibit the growth of $S$. aureus that was resistant to the extract.

However, in our study, significant differences were observed between extracts from various $C$. tomentosa plant tissues, which had antibacterial activities against $B$. subtilis and $S$. aureus. The results suggested that $B$. subtilis and $S$. aureus were susceptible to fruit and leaf extracts of $C$. tomentosa at $500-1,000 \mu \mathrm{g} / \mathrm{disc}$. Thus, this is the first time that the antibacterial activity of $C$. tomentosa has been documented by direct observations of bacterial populations. The leaf extract was more potent against $B$. subtilis than the fruit extract, whereas the extract activities against $S$. aureus had the reverse order. Unfortunately, a stem bark extract of $C$. tomentosa did not exhibit any antibacterial activity in the current study. The root of this plant has been prescribed in Thai traditional medicine to treat infectious diseases such as stomatitis and ulcer [6], but the current study is the first to report the efficacy of fruit and leaf extracts against the growth of pathogenic bacteria.

Medicinal plants have been traditionally used for the treatment of diseases caused by microorganisms, and the extracts and bioactive compounds from medicinal plants target a wide range of infections in holistic health care. Research on plant-derived substances, which confirmed their activities and determined their specific mechanisms of action against pathogenic organisms, has been widely pursued $[8,9]$. In the current study, the response patterns of bacterial populations to plant extracts showed changes in granularity and membrane permeability. Time and dose dependence of the responses were assessed, to clarify how the $C$. tomentosa extracts inhibited the growth of these pathogenic bacteria. We observed the bacterial death rates and the changes in granularity and membrane permeability using FACS.

FACS profiles showed that both extracts were active against bacteria, with consistent trends in the death rates. The granularity of the bacteria was lost and the bacterial membranes were damaged by the tested treatments. Most studies have suggested that plant extracts inhibited the growth of bacteria by damaging the cell wall and the cell membrane, thus increasing membrane permeability and causing death of the bacteria [8-10]. By using FACS, we found that increasing the extract dose caused further loss of granularity, and of intracellular functions, subsequently inducing cell membrane injuries, and eventually leading to cell death. Although the outer membrane of a bacterium plays an important role in protecting the cell, permeability of the membrane of Gram positive bacteria could allow a drug to infiltrate into the cell without its disruption [11]. 
Thus, because the cell first lost granularity, the plant extracts might have played an important role as DNA-damaging agents that were able to penetrate through the cell membrane, and subsequently induce activation of autolysisinduced proteins (i.e., autolysin). The action of autolysin could cause membrane digestion leading to death, indicating programmed death of the bacteria [12]. The patterns of bacterial responses to plant extracts have been explored in recent years, and in one study [10], the cell integrity was lost followed by cytoplasmic content leaking out of the cells and nuclear areas.

However, the mechanisms observed in our current study included changes to granularity and membrane permeability, so that the $C$. tomentosa extracts might act by inducing programmed death in the targeted bacteria. The population of injured cells may be crucial if cell recovery becomes possible [13], as in the development of microbial resistance.

Description of the mode of the action of these extracts could stimulate the search for new antibiotics and the exploration of programmed cell death pathways in bacteria. Multiple mechanisms may be involved, such as loss of granularity and damage to the cell membrane. This is the first report documenting both intracellular changes and outer membrane loss in bacteria exposed to plant extracts. Because the physiological roles of genes involved in programmed cell death are not precisely known for the tested bacteria, the proteins involved in the pathways of bacterial death could be studied in further experiments for a more detailed understanding of how they are involved in the process of programmed cell death.

\section{CONCLUSION}

C. tomentosa extracts are potential sources of antibacterial agents against various pathogenic bacteria. The antibacterial effects of the extracts include programmed death of bacteria, starting with granularity changes and DNA damage (injured cells), followed by permeability changes in membranes (membrane-damaged cells), and eventually leading to death. Programmed cell death-mediated proteins should be investigated in future experiments.

\section{DECLARATIONS}

\section{Acknowledgement}

The authors would like to thank Associate Professor Dr. Seppo Karrila for assistance with the manuscript preparation. This work was financially supported by the Prince of Songkla University, Suratthani Campus (2016).

\section{Conflict of Interest}

No conflict of interest associated with this work.

\section{Contribution of Authors}

The authors declare that this work was done by the authors named in this article and all liabilities pertaining to claims relating to the content of this article will be borne by them.

\section{REFERENCES}

1. Lee A, O'Rourke J. Gastric bacteria other than Helicobacter pylori. Gastroenterol Clin North Am 1993; 22: 21-42.

2. Mailles A, Stahl JP. Infectious Encephalitis in France in 2007: A National Prospective Study. Clin Infect Dis 2009; 49: 1838-1847.

3. Bernhoft A. A brief review on bioactive compounds in plants, in: A. Bernhoft (Ed), Bioactive compounds in plants: benefits and risks for man and animals, The Norwegian Academy of Science and Letters, Oslo 2008 pp 255.

4. Al-Qurainy F, Gaafar AR, Khan S, Nadeem M, Tarroum M, Alaklabi A, et al. Antibacterial activity of leaf extract of Breonadia salicina (Rubiaceae), an endangered medicinal plant of Saudi Arabia. Genet Mol Res 2013; 12: 3212-3219.

5. Elumalai EK, Prasad TNVKV, Hemachandran J, Therasa SV, Thirumalai T, David E, Extracellular synthesis of silver nanoparticles using leaves of Euphorbia hirta and their antibacterial activities. J Pharm Sci Res 2010; 2 : 549-554.

6. Wutithamawech $W$, Tantirungkij $M$, Liangsakul $P$. Antibacterial potential of some Thai medicinal plants. Int J Pharm Bio Sci 2014; 5: 412-421.

7. Musimun $C$, Chuysongmuang $M$, Permpoonpattana $P$, Chumkaew $P$, Sontikul $Y$, Ummarat $N$, et al. FACS analysis of bacterial responses to extracts of Vatica diospyroides fruit show dose and time dependent induction pattern. Walailak J Sci Tech 2017; 14 (11): 883-891.

8. Li H, Yang T, Li FY, Tao Y, Sun ZM. Antibacterial activity and mechanism of action of Monarda punctata essential oil and its main components against common bacterial pathogens in respiratory tract. Int J Clin Exp Pathol 2014; 7: 7389-7398.

9. Yong $A L$, Ooh KF, Ong HC, Chai TT, Wong FC. Investigation of antibacterial mechanism and identification of bacterial protein targets mediated by antibacterial plant extracts. Food Chem 2015; 186: 3236.

10. Peng L, Kang S, Yin Z, Jia R, Song $X$, Li L, et al. Antibacterial activity and mechanism of berberine

Trop J Pharm Res, May 2018; 17(5): 881 
against Streptococcus agalactiae. Int J Clin Exp Pathol 2015; 8: 5217-5223.

11. Hong J, Guanc W, Jina G, Zhaoa H, Jianga X, Daia J. Mechanism of tachyplesin I injury to bacterial membranes and intracellular enzymes, determined by laser confocal scanning microscopy and flow cytometry. J Microbiol Res 2015; 170: 69-77.
12. Lewis K, Programmed death in bacteria. Microbiol Mol Biol Rev 2000; 64: 503-514.

13. Balouiri M, Sadiki M, Ibnsouda SK. Methods for in vitro evaluating antimicrobial activity: A review. J Pharm Analysis 2016; 6: 71-79. 